This document is a manuscript version of the following article:

Title: Aluminium alloy based hydrogen storage tank operated with sodium aluminium hexahydride $\mathrm{Na}_{3} \mathrm{AlH}_{6}$

By: Urbanczyk, Robert; Peinecke, Kateryna; Felderhoff, Michael; Hauschild, Klaus; Kersten, Wolfgang; Peil, Stefan; Bathen, Dieter

Published in: International Journal of Hydrogen Energy

Volume 39, Issue 30, 13 October 2014, Pages 17118-17128

Publisher: Elsevier | Year: 2014

DOI: 10.1016/j.jijhydene.2014.08.101

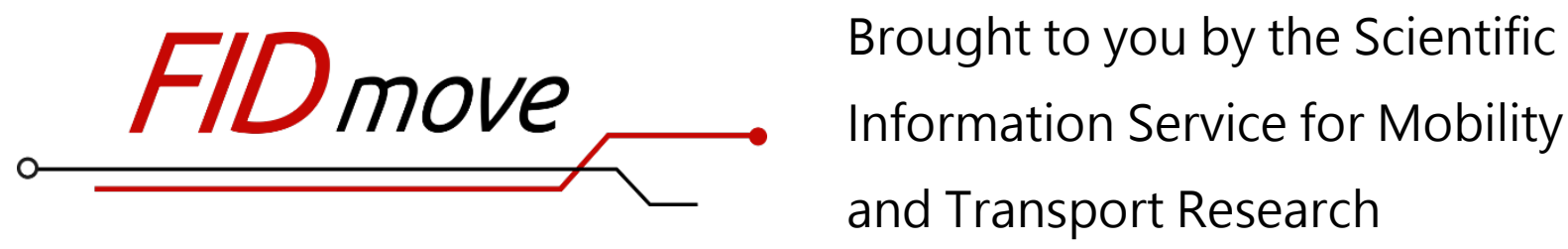

Fachinformationsdienst Mobilitäts- und Verkehrsforschung

Website: www.fid-move.de

Repository: publish.fid-move.de

Contact: publish@fid-move.de

(C) 2014. This manuscript version is made available under the CC-BYNC-ND 4.0 license.

http://creativecommons.org/licenses/by-nc-nd/4.0/ 


\title{
Aluminium alloy based hydrogen storage tank operated with sodium aluminium hexahydride $\mathrm{Na}_{3} \mathrm{AlH}_{6}$
}

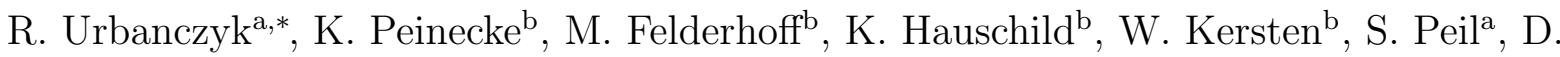 \\ Bathen $^{\mathrm{a}}$ \\ ${ }^{a}$ Institut für Energie- und Umwelttechnik e.V., Bliersheimerstr. 58-60, 47229 Duisburg \\ ${ }^{b}$ Max-Planck-Institut für Kohlenforschung, Kaiser-Wilhelm-Platz 1, 45470 Mülheim an der Ruhr
}

\begin{abstract}
Here we present the development of an aluminium alloy based hydrogen storage tank, charged with Ti-doped sodium aluminium hexahydride $\mathrm{Na}_{3} \mathrm{AlH}_{6}$. This hydride has a theoretical hydrogen storage capacity of 3 mass- $\%$ and can be operated at lower pressure compared to sodium alanate $\mathrm{NaAlH}_{4}$. The tank was made of aluminium alloy EN AW $6082 \mathrm{~T} 6$. The heat transfer was realised through an oil flow in a bayonet heat exchanger, manufactured by extrusion moulding from aluminium alloy EN AW $6060 \mathrm{~T} 6$. $\mathrm{Na}_{3} \mathrm{AlH} \mathrm{H}_{6}$ is prepared from 4 mol-\% $\mathrm{TiCl}_{3}$ doped sodium aluminium tetrahydride $\mathrm{NaAlH}_{4}$ by addition of two moles of sodium hydride $\mathrm{NaH}$ in ball milling process. The hydrogen storage tank was filled with $213 \mathrm{~g}$ of doped $\mathrm{Na}_{3} \mathrm{AlH}_{6}$ in dehydrogenated state. Maximum of $3.6 \mathrm{~g}$ (1.7 mass-\% of the hydride mass) of hydrogen was released from the hydride at approximately $450 \mathrm{~K}$ and the same hydrogen mass was consumed at $2.5 \mathrm{MPa}$ hydrogenation pressure. 45 cycle tests (rehydrogenation and dehydrogenation) were carried out without any failure of the tank or its components. Operation of the tank under real conditions indicated the possibility for applications with stationary HT-PEM fuel cell systems.
\end{abstract}

Keywords: hydrogen storage, complex hydride, $\mathrm{Na}_{3} \mathrm{AlH}$, aluminium alloy, extrusion moulding

\footnotetext{
*Corresponding author. Tel.: +49 2065418 224; fax: +49 2065418211

Email address: urbanczyk@iuta.de (R. Urbanczyk)

$U R L$ : www.iuta.de (R. Urbanczyk)
} 


\section{Introduction}

3

4

5 f

6

7

8

9

Over the last years the use of different hydrogen based techniques for transportation, electricity production or energy storage has been widely discussed (Schlapbach and Zuttel, 2001; Weidenthaler and Felderhoff, 2011). Currently the hydrogen storage method for fuel cell powered vehicles seems to be $70 \mathrm{MPa}$ compressed hydrogen (Eberle et al., 2012). Whereas the liquid hydrogen storage has been discussed to be used in aviation systems (Verstraete et al., 2010; Renouard-Vallet et al., 2012), the solid hydrogen storage in metal hydrides has already been implemented in submarines powered by fuel cells (Sattler, 2000, Psoma and Sattler, 2002). Besides of their high volumetric hydrogen storage density, metal hydrides offer high heat storage capacities (Bogdanović et al., 1989; Wierse et al., 1991). [Therefore they could be used in applications like heat pumps, cooling systems (Willers and Groll, 1999; Muthukumar and Groll, 2010), heat transformers (Kang and Yabe, 1996), heat driven gas compressors (Li et al., 2010) or finally gas purifiers (Miura et al., 2012).

Sodium aluminium tetrahydride $\mathrm{NaAlH}_{4}$ (sodium alanate) is a well known complex metal hydride, which kinetics was tremendously enhanced by Ti-dopants (Bogdanović and Schwickardi, 1997). Sodium alanate releases or consumes hydrogen in a two step reaction (cf. Equations 1 and 2). $\mathrm{NaAlH}_{4}$, a low temperature hydride, has an equilibrium pressure of $0.1 \mathrm{MPa}$ at approximately $300 \mathrm{~K}$, whereas the second decomposition phase $\mathrm{Na}_{3} \mathrm{AlH}_{6}$ (sodium aluminium hexahydride), a medium temperature hydride, has an equilibrium pressure of $0.1 \mathrm{MPa}$ at approximately $373 \mathrm{~K}$. The reaction enthalpies are $37 \mathrm{~kJ} / \mathrm{mol}_{\mathrm{H}_{2}}$ for the first step and $47 \mathrm{~kJ} / \mathrm{mol}_{\mathrm{H}_{2}}$ for the second step respectively (Bogdanović and Schwickardi, 1997). Therefore $\mathrm{NaAlH}_{4}$ or only $\mathrm{Na}_{3} \mathrm{AlH}_{6}$, which characteristics have not yet been investigated, can be used as both hydrogen and heat storage material in CHP (Combined Heat and Power) systems for household applications, for instance combined with a HT-PEM fuel cell. Such additional heat storage possibility could prolong the operation time of the fuel cell based CHP system in stationary applications (Urbanczyk et al., 2012).

Both theoretical (Jensen et al., 2005; Pfeifer et al., 2009; Reddy and Jayanti, 2012) and practical investigations (Urbanczyk et al., 2011; Weiss-Ungethüm et al., 2014; Urbanczyk, 
2014) were carried out to demonstrate the thermal coupling of $\mathrm{NaAlH}_{4}$ based hydrogen storage tanks in combination with a HT-PEM fuel cell. While in one case air was proposed as a heat transfer medium between the tank and fuel cell (Utz et al. 2011$)$, in other cases a liquid was used for the thermal coupling. Another complex hydride $\left(2 \mathrm{LiNH}_{2}-\right.$ $1.1 \mathrm{MgH}_{2}-0.1 \mathrm{LiBH}_{4}-3$ mass- $\left.\% \mathrm{ZrCoH}_{3}\right)$ and a combination of it with a metal hydride $\left(L a N i_{4.3} A l_{0.4} M n_{0.3}\right)$ was also proposed as a solid hydrogen storage system thermally coupled with a HT-PEM fuel cell (Bürger et al., 2014b c a).

For the evaluation of a storage system the overall performance of the complete system (tank system plus storage material) is quite important. Therefore a lightweight material for the tank systems in combination with a hydrogen storage material with even relatively low hydrogen capacity promises several advantages (for example regarding the gravimetric hydrogen storage capacity of the system). To the best of our knowledge, until now, aluminium alloy based tank systems in combination with complex metal hydrides were never explored as a hydrogen storage system. Ti-doped $\mathrm{Na}_{3} \mathrm{AlH}_{6}$ was selected as hydrogen storage material, because its properties $\left(453.15 \mathrm{~K}\right.$ operating temperature, $\left.p_{\max }=2.5 \mathrm{MPa}\right)$ fit very well to the mechanical load limits of the selected aluminium alloy.

\section{Materials and calculations}

\subsection{Synthesis of doped $\mathrm{Na}_{3} \mathrm{AlH} \mathrm{H}_{6}$}

According to equations 1 and 2 sodium alanate can be decomposed in a two step reaction. In the first reaction theoretical 3.7 mass- $\%$ of hydrogen can be released. The hexahydride phase decomposes with theoretical 1.8 mass-\% hydrogen content (Bogdanović et al., 2007).

$$
3 \mathrm{NaAlH}_{4} \rightleftharpoons \mathrm{Na}_{3} \mathrm{AlH}_{6}+2 \mathrm{Al}+3 \mathrm{H}_{2}
$$

$$
\mathrm{Na}_{3} \mathrm{AlH}_{6}+2 \mathrm{Al} \rightleftharpoons 3 \mathrm{NaH}+3 \mathrm{Al}+\frac{3}{2} \mathrm{H}_{2}
$$

Without additional aluminium, sodium aluminium hexahydride releases theoretical 3 mass$\%$ hydrogen, according to reaction 3 .

$$
\mathrm{Na}_{3} \mathrm{AlH}_{6} \rightleftharpoons 3 \mathrm{NaH}+\mathrm{Al}+\frac{3}{2} \mathrm{H}_{2}
$$




$$
\mathrm{NaAlH}_{4}+2 \mathrm{NaH} \rightleftharpoons \mathrm{Na}_{3} \mathrm{AlH}_{6}
$$

Parameters for the synthesis are given in Table 1. Prior to filling material into the hydro-

Table 1: Ball milling parameters for synthesis of $\mathrm{Na}_{3} \mathrm{AlH}_{6}$

\begin{tabular}{|c|c|c|c|c|c|}
\hline volume ${ }^{1}[\mathrm{ml}]$ & No. of balls $[-]$ & $\mathrm{Na}_{3} \mathrm{AlH}_{6}[\mathrm{~g}]$ & rotat. freq. $[\mathrm{rpm}]$ & milling time $[\mathrm{h}]$ & $\mathrm{BPR}^{2}[-]$ \\
\hline 500 & 25 & 50 & 250 & 2 & $30: 1$ \\
\hline
\end{tabular}



first 30 min of every cycle.

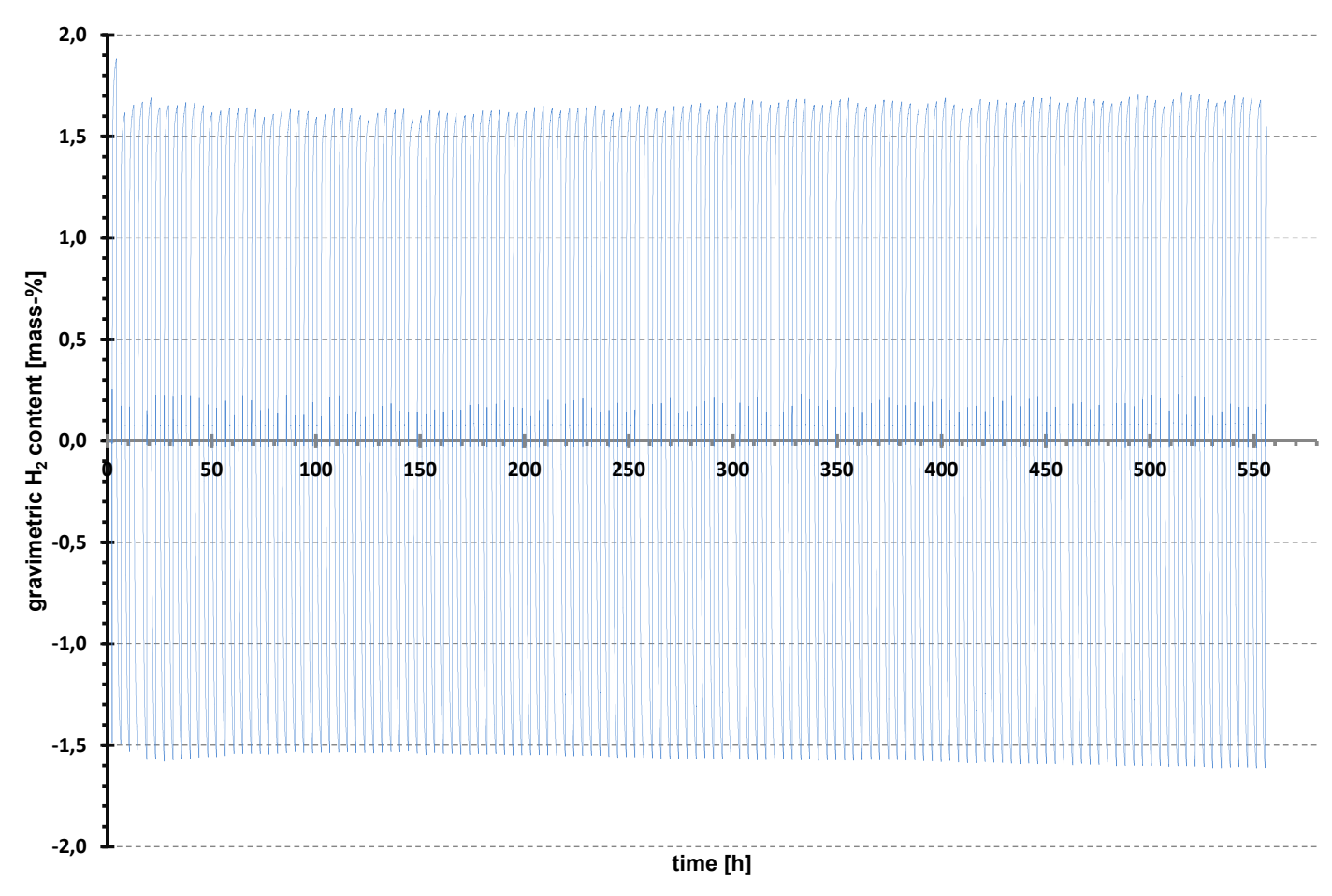

Figure 1: Long term cycling of $\mathrm{Na}_{3} \mathrm{AlH}_{6}+4.0$ mol- $\% \mathrm{TiCl}_{3}$

using PCTPro (Setaram), a fully automated Sieverts instrument for measuring gas sorption properties of materials. $2 \mathrm{~g}$ of material was placed into a specially designed tube like sample holder. In total 275 two-hour-hydrogenation/dehydrogenation cycles were achieved without degradation. Every hydrogenation cycle was performed at $2.5 \mathrm{MPa}$ hydrogen pressure and $443.15 \mathrm{~K}$, while every dehydrogenation cycle was performed at ambient hydrogen pressure and 443.15 K. 1.7 mass-\% of hydrogen was evolved and absorbed during hydrogenation or dehydrogenation (Figure 1). $80 \%$ of the total hydrogen amount is evolved or absorbed during

\subsection{Comparison between the tetra and hexa aluminium hydrides}

A typical hydrogenation pressure for $\mathrm{NaAlH}_{4}$ is $10 \mathrm{MPa}$ and higher (Lozano et al., 2009, Johnson et al., 2011). The typical hydrogenation pressure for the $\mathrm{Na}_{3} \mathrm{AlH}_{6}$ formation is approximately four times lower, compared to the hydrogenation pressure of $\mathrm{NaAlH}_{4}$ at the same temperature. The hydrogenation of $3 \mathrm{NaH}+A l$ system can be carried out at a pressure 
around 2.5 MPa. The energy demand (specific work $w_{t}$ ) for hydrogen compression from the low pressure $p_{1}$ up to the high pressure $p_{2}$ can be calculated by using the equation for the isentropic enthalpy difference $\Delta h_{s}$. The specific compression work $w_{t}$ from the starting temperature $T_{1}$ can be written as shown in Equation 5 (Baehr and Kabelac, 2009):

$$
w_{t}=\Delta h_{s}=\frac{\kappa}{\kappa-1} \cdot R \cdot T_{1} \cdot\left[\left(\frac{p_{2}}{p_{1}}\right)^{\frac{\kappa-1}{\kappa}}-1\right]
$$

$R$ is the specific gas constant and $\kappa$ the isentropic exponent for hydrogen.

The isentropic work for hydrogen compression can be put in relation to the low heating value of hydrogen $\mathrm{LHV}_{\mathrm{H}_{2}}$, which is shown in Figure 2. It can be seen in the figure that the

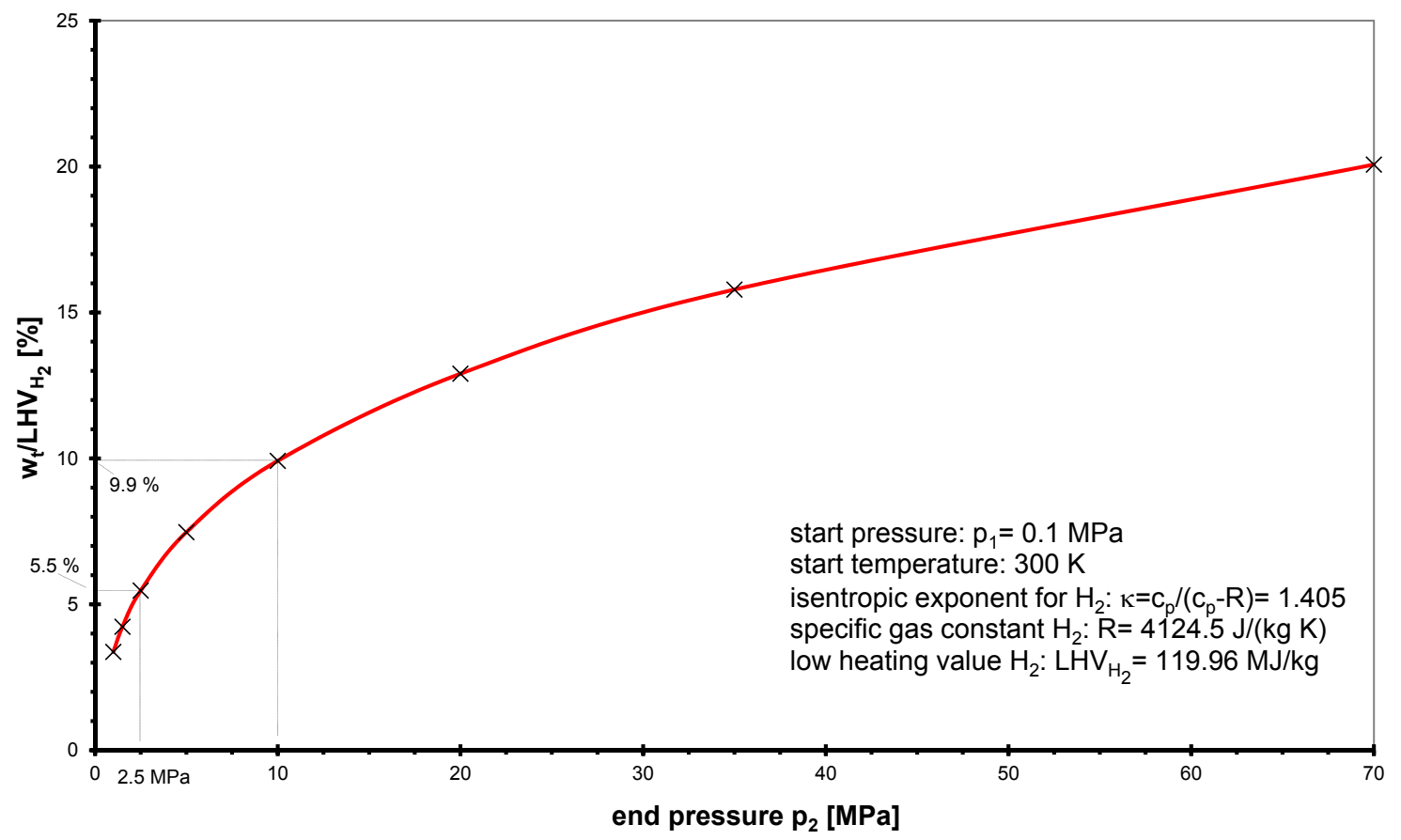

Figure 2: Energy demand for isentropic compression of hydrogen. Thermophysical data according to Baehr and Kabelac, 2009)

93

energy demand for the compression of hydrogen up to $10 \mathrm{MPa}$ is approximately 1.8 times higher compared to the compression up to $2.5 \mathrm{MPa}$. It should be noted that compressors are not working isentropic. They work irreversible with entropy production and some of them can be cooled down using several cooling loops (Jepsen et al., 2012). This additional cooling shifts the compression closer to the ideal isothermal compression process, in which 
Table 2: Assumptions I for considered complex hydrides

\begin{tabular}{|c|c|c|c|c|}
\hline & density $\left[\mathrm{kg} / \mathrm{m}^{3}\right]$ & max. pressure $[\mathrm{MPa}]$ & $\xi_{H_{2}}[$ mass $-\%]$ & $\psi_{\text {dopant }}[\mathrm{mol}-\%]$ \\
\hline $\mathrm{NaAlH}_{4}{ }^{1}$ & 720 & 10 & 3.5 & $3^{2}$ \\
\hline $\mathrm{Na}_{3} \mathrm{AlH}_{6}$ & variable & 2.5 & 1.95 & $4^{3}$ \\
\hline
\end{tabular}

Table 3: Assumptions II for considered tank materials

\begin{tabular}{lcccc}
\hline & density $\left[\mathrm{kg} / \mathrm{m}^{3}\right]$ & pressure $[\mathrm{MPa}]$ & yield strength $[\mathrm{MPa}]$ & temperature $[\mathrm{K}]$ \\
\hline austenitic steel $^{1}$ & 8000 & 10 & $R p_{1,0}=190$ & 473.15 \\
aluminium alloy $^{2}$ & 2700 & 5 & $R p_{0,2}=162.5$ & 473.15 \\
\hline
\end{tabular}

1 1.4571 (DIN EN 10027-2:1992)

2 EN AW 6082 T6 (DIN EN 573-2:1994 and DIN EN 515:1993; Ostermann 2007) 
depends on the mass of stored hydrogen and the volume of the tank. Higher hydrogen mass is achievable if either high hydrogen content of the hydride is available or the hydride powder is densified. For energy density comparison between an Aluminium Alloy Tank charged with $\mathrm{Na}_{3} \mathrm{AlH}_{6}$ (AAT) and a Steel Alloy Tank charged with $\mathrm{NaAlH}_{4}$ (SAT) a variable $x$ is defined, which describes the ratio of the respective hydride densities of $\mathrm{Na}_{3} \mathrm{AlH}_{6}$ and $\mathrm{NaAlH}_{4}$, (Equation 7).

$$
x=\frac{\rho_{N a_{3} A l H_{6}}}{\rho_{N a A l H_{4}}}
$$

The gravimetric energy density $e_{g}$ of the system means the ratio of stored hydrogen energy $\left(m_{H_{2}} \cdot L H V\right)$ per $\mathrm{kg}$ of the system mass $m_{S y s}$ (cf. Equation 8).

$$
e_{g}=\frac{m_{H_{2}} \cdot L H V}{m_{\text {Sys }}}
$$

The volumetric energy density of the system $e_{v}$ means the ratio of stored hydrogen energy $\left(m_{H_{2}} \cdot L H V\right)$ per $\mathrm{m}^{3}$ system volume $V_{\text {Sys }}($ cf. Equation 9).

$$
e_{v}=\frac{m_{H_{2}} \cdot L H V}{V_{S y s}}
$$

In Figure 3 the ratio $Z$ of the gravimetric energy densities of both systems AAT and SAT

$$
Z=\frac{e_{g, A A T}}{e_{g, S A T}}
$$

is shown on the left ordinate, whereas on the right ordinate the ratio $Y$ of volumetric energy densities

$$
Y=\frac{e_{v, A A T}}{e_{v, S A T}}
$$

is shown.

The data of a hydrogen content of 3.5 mass- $\%$ and a hydride density of $720 \mathrm{~kg} / \mathrm{m}^{3}$ (sodium alanate), that was used in the calculations, was taken from Mosher et al. (Mosher et al. 2007). Other research groups have achieved different results of hydrogen content and hydride density of the used hydrides. A hydrogen content of 4.5 mass- $\%$ and a hydride density of $1600 \mathrm{~kg} / \mathrm{m}^{3}$ were achieved by Lozano et al.(Lozano et al., 2011), while a hydrogen content of 3.4 mass- $\%$ and a hydride density of $1470 \mathrm{~kg} / \mathrm{m}^{3}$ were accomplished by van Hassel et al. van Hassel et al., 2012). 


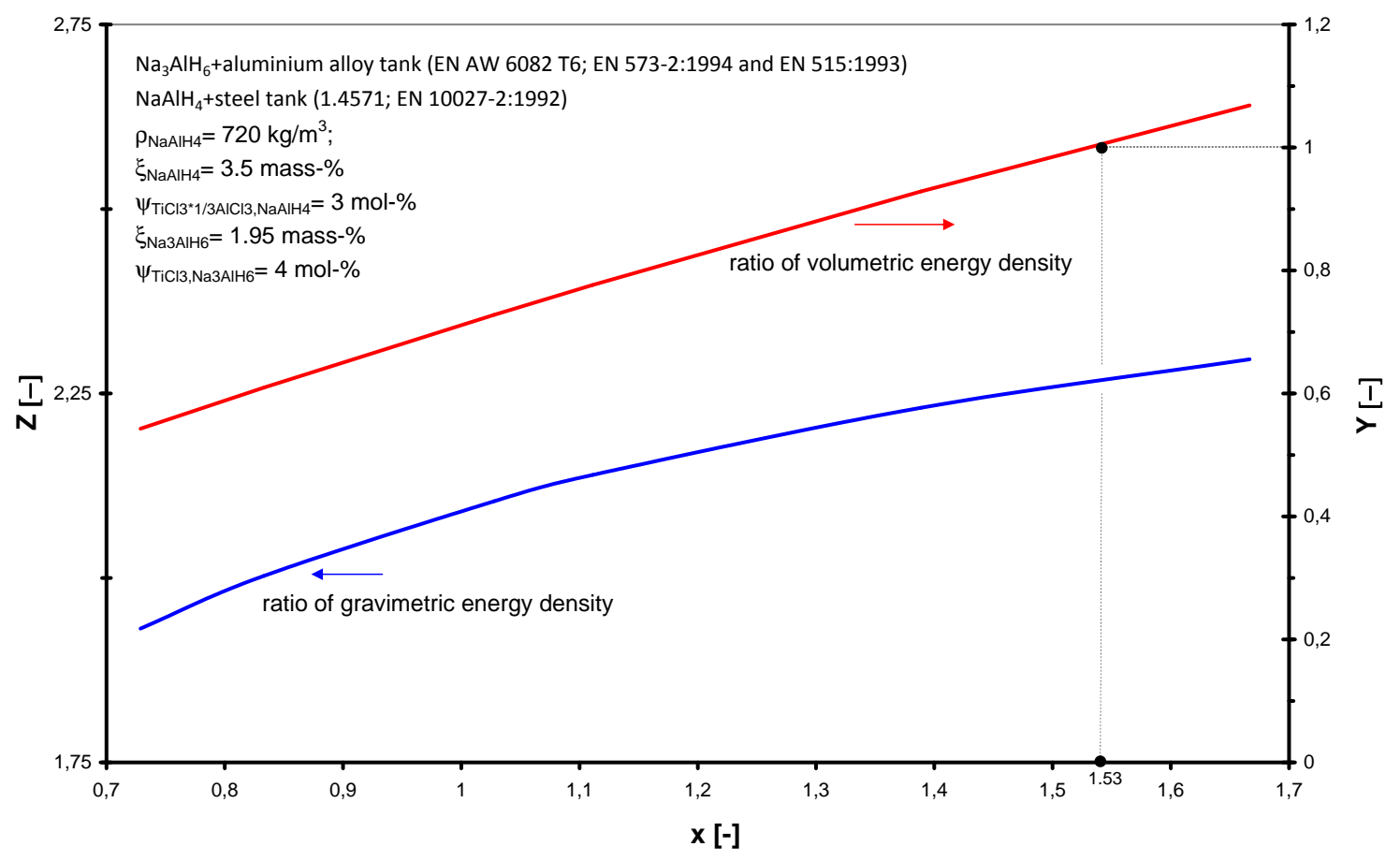

Figure 3: Ratios of gravimetric $Z=\frac{e_{g, A A T}}{e_{g, S A T}}$ and volumetric $Y=\frac{e_{v, A A T}}{e_{v, S A T}}$ hydrogen densities vs. the hydride density ratio $x=\frac{\rho_{\mathrm{Na}_{3} \mathrm{AlH}}}{\rho_{\mathrm{NaAlH}_{4}}}$. 
Wall thickness of the pressure tank, dimensions of flanges and lids were calculated according to technical data and safety regulations (AD Merkblätter, 2002). Based on these dimensions the volumes and from known densities of the tank alloys (steel and aluminium in Table 3) the masses of the tanks were calculated. The calculated wall thickness depends on the diameter of the tank (cylindrical shape) and influences the mass of the tank AD Merkblätter, 2002). Because of the different material densities and hydrogen contents of $\mathrm{Na}_{3} \mathrm{AlH}_{6}$ and $\mathrm{NaAlH}_{4}$, the respective hydride volumes are not the same for storage of equal mass of hydrogen. The mass and volume of the SAT were calculated according to the values in Tables 2 and 3 and were kept constant. For comparison, only the length of the respective aluminium tank (AAT) was changed according to $\mathrm{Na}_{3} \mathrm{AlH} \mathrm{H}_{6}$ density, while the inner exemplary diameter $(117.4 \mathrm{~mm})$ of the both tank systems AAT and SAT was left the same .

Figure 3 shows, that the gravimetric energy density (gravimetric hydrogen density) is higher in case of the AAT for all hydride density ratios. The volumetric energy density (volumetric hydrogen density) is lower in case of the AAT if the hydride density ratio is less than 1.5. In this comparison the mass and the volume of connectors, hydrogen distribution and heat transfer system were not taken into account. It can be concluded, that, despite of the lower hydrogen content of $\mathrm{Na}_{3} \mathrm{AlH}_{6}$ in comparison to $\mathrm{NaAlH}_{4}$, an exemplary aluminium alloy tank filled with $\mathrm{Na}_{3} \mathrm{AlH}_{6}$ has a considerable potential with regard to the operational procedure (Figure 2) and gravimetric energy density (Figure 3) of the whole system.

\subsection{Aluminium alloy based hydrogen storage tank}

The hydrogen storage tank and the heat exchanger were manufactured from aluminium based alloys (EN AW 6082 T6 and EN AW 6060 T6) characterized according to the European standards $((\overline{E N ~ 12392, ~ 2000 ; ~ E N ~ 13445, ~ 2009) ~})$. The pressure vessel was developed for maximum operational temperature of $473.15 \mathrm{~K}$, although such a high temperature was not expected. The yield stress of EN AW 6082 T6 of $162.5 \mathrm{MPa}$ at $473.15 \mathrm{~K}$ was taken from Ostermann, 2007). While decreasing of the yield stress at higher temperature over time $(>2 h)$ has been unknown, the tank has been designed for higher hydrogenation pressure 
(5 MPa) than applied under realistic conditions (2.5 MPa cf. Table 2). At 2.5 MPa hydrogen pressure the tank could be theotetically operated up to $563.15 \mathrm{~K}$. In addition a safety factor of 1.5 was used for the calculation of dimensions (AD Merkblätter, 2002). The tube of the heat exchanger has orthogonal fins to increase material strength against the pressure of the reacting metal hydride at the outer side of the heat exchanger. Thermal oil flows inside of the tube at a pressure, which is high enough to overcome the pressure drops in the oil circuit. In one of the strength experiments, which were carried out in a similar steel tank without $\mathrm{Na}_{3} \mathrm{AlH}_{6}$, the heat exchanger withstood an outer pressure of $20 \mathrm{MPa}$ (at ambient temperature), whereas inside of the heat exchanger tube only ambient pressure prevailed. It was constructed as a bayonet heat exchanger with reversal oil flow inside of the tube, achieved by a small steel capillary, which was inserted into the finned heat exchanger tube. One end of the tube was closed by laser welding while the other end was laser welded to the lid. The aluminium tank with integrated aluminium heat exchanger is shown in Figure 4.

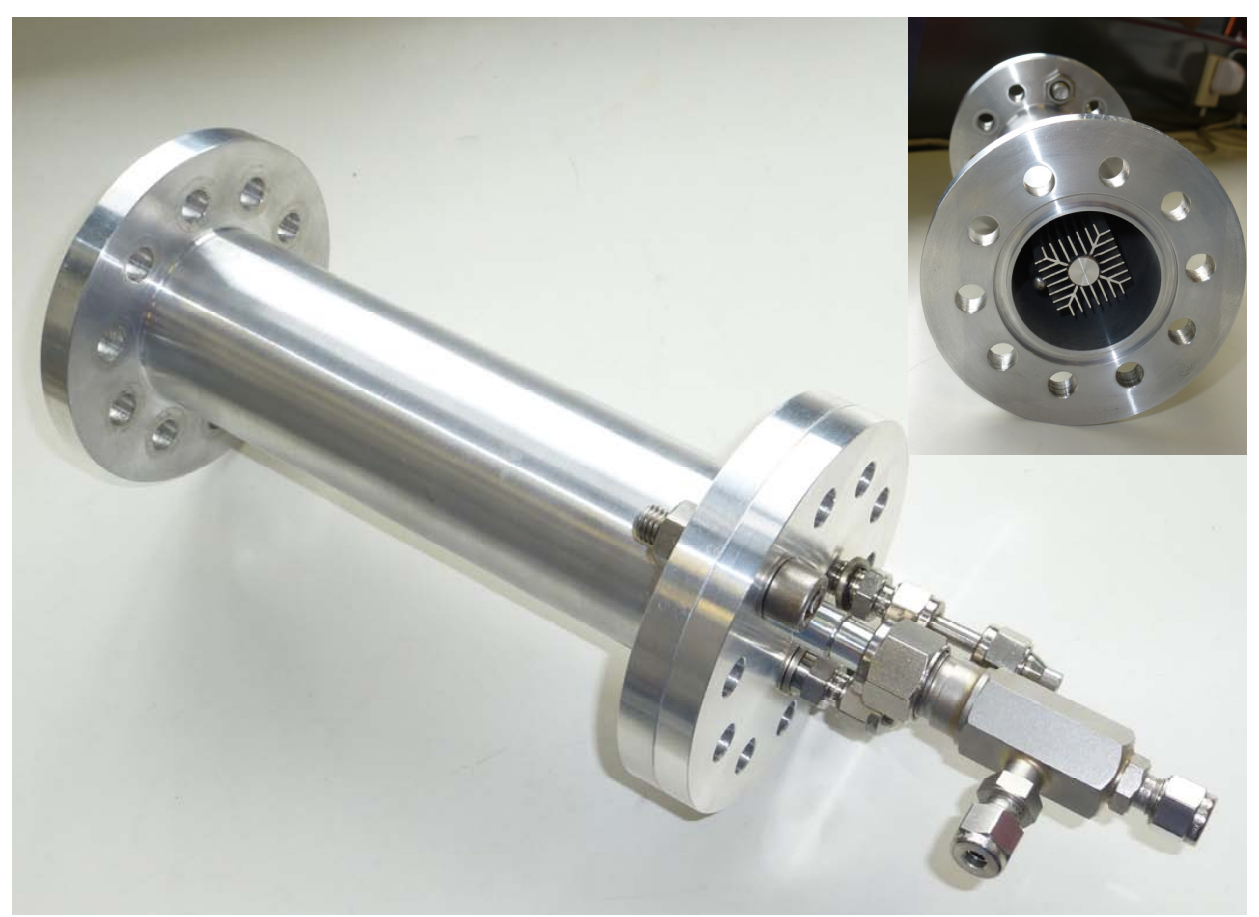

Figure 4: Aluminium alloy tank. The heat exchanger can be seen from the open side of the tank. 
EN AW 6060 T6 aluminium alloy, are given in Table 4.

Table 4: Data of the bayonet type EN AW 6060 T6 heat exchanger

\begin{tabular}{lcc}
\hline number of orthogonal fins $^{1}$ & 28 & {$[-]$} \\
number of radial fins $^{2}$ & 4 & {$[-]$} \\
fin thickness $^{3}$ & 0.6 & {$[\mathrm{~mm}]$} \\
fin clearance $^{4}$ & 2.8 & {$[\mathrm{~mm}]$} \\
fin height (minimal/maximal) & $4.5 / 10$ & {$[\mathrm{~mm}]$} \\
fin length & 205 & {$[\mathrm{~mm}]$} \\
heat exchange area & 0.103 & {$\left[\mathrm{~m}^{2}\right]$} \\
mass of finned length & 118.1 & {$[\mathrm{~g}]$} \\
heat exchange tube (inner diameter/wall thickness) & $10.1 / 1.1$ & {$[\mathrm{~mm}]$} \\
bayonet tube (outer diameter/wall thickness) & $8 / 0.5$ & {$[\mathrm{~mm}]$} \\
\hline $\begin{array}{l}1 \\
2 \text { fin distribution shown in Figures } 7 \text { and } 9\end{array}$ & & \\
${ }^{3}$ as fin fip orthogonal fins \\
4 at fin tip, orthogonal fins
\end{tabular}

All mass of the most important components of the tank can be found in Table 5 . The overall mass of the tank system consisting of aluminium alloys based components was $1380.4 \mathrm{~g}$ with a free inner volume of $414 \mathrm{ml}$ available for the metal hydride. The total mass of the

Table 5: Mass of the particular components of the tank in [g]

\begin{tabular}{cccccccc}
\hline tank & lid I & lid II & sealings & $H_{2}$-distribution & heat exchanger & bayonet tube & screws \\
\hline 698.2 & $303^{1}$ & $263.5^{2}$ & 9.4 & 75,3 & 115.7 & 17.6 & 913.4 \\
\hline
\end{tabular}

1 only for opening/closing purpose

2 this lid is welded to the heat exchanger

tank and the listed components including $216.6 \mathrm{~g}$ of hydrogenated $\mathrm{Na}_{3} \mathrm{AlH}_{6}\left(3.6 \mathrm{~g} \mathrm{H}_{2}\right)$ was $2612.7 \mathrm{~g}$. As a result the gravimetric hydrogen density of 0.14 mass- $\%$ and the volumetric hydrogen density of $3.7 \mathrm{~kg} / \mathrm{m}^{3}$ (overall tank volume $990.3 \mathrm{ml}$ ) was achieved. The mass of the assembled tank including thermocouples with appropriate fittings and oil distribution system for the bayonet heat exchanger was $3805.4 \mathrm{~g}$. Although these values are far away from the results achieved for example by Mosher et al. (2.0 mass- $\%$ and $21.0 \mathrm{~kg} / \mathrm{m}^{3}$ with carbon 

procedures are depicted in Figure 5

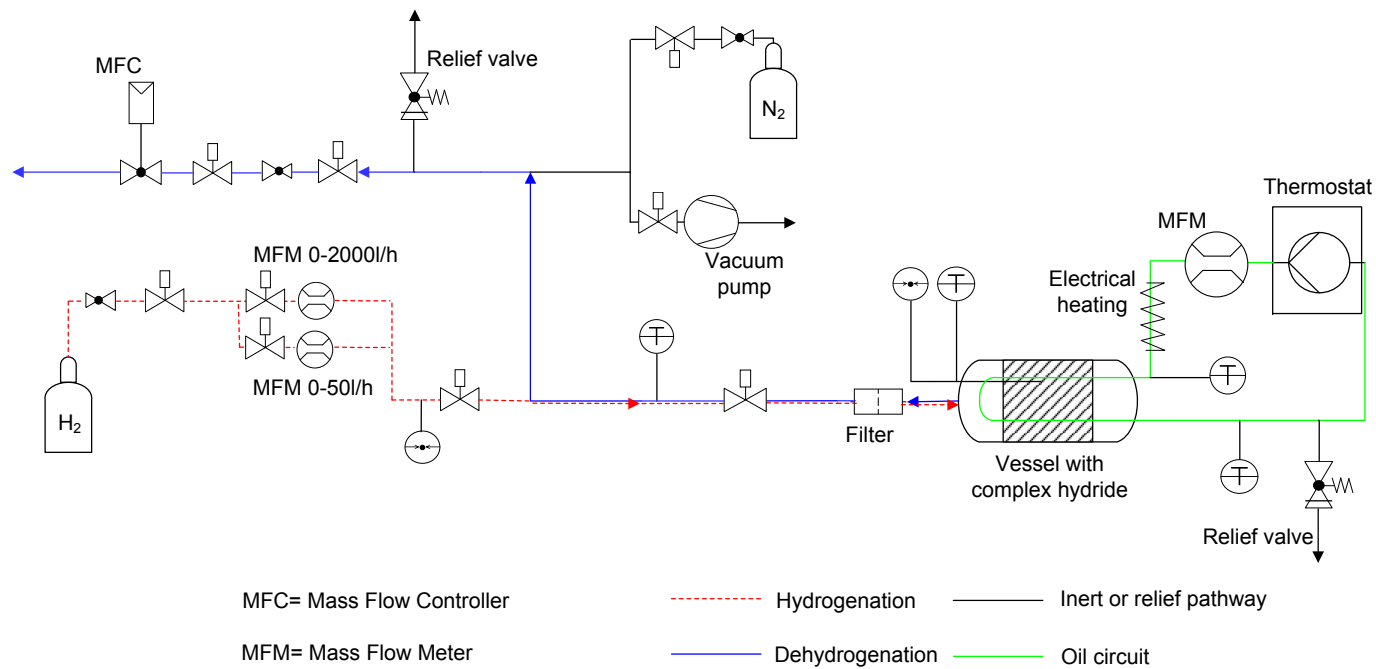

Figure 5: Aluminium alloy tank integrated in test rig 
In case of hydrogenation experiments the hydride was heated by both thermostat via thermal oil and electrical heating until the temperature in the material reached a value between 423.15 and $443.15 \mathrm{~K}$. Afterwards hydrogen at a pressure of $2.5 \mathrm{MPa}$ was introduced into the tank. The hydrogen (5.0 purity grade) was prvided from 501, $20 \mathrm{MPa}$ cylinders. Because of heat evolution during the hydrogenation, electrical heating was switched off and in some experiments the thermostat cooled down the tank.

It was important to hold the temperature during the dehydrogenation step constantly above $453.15 \mathrm{~K}$, because of non-optimized kinetics of the hydride. Dehydrogenation was started after the controlled temperatures inside the tank reached more than $453.15 \mathrm{~K}$.

\subsection{Tests of the sodium aluminium hexahydride}

The tank (inner volume $414 \mathrm{ml}$ ) was filled with $213 \mathrm{~g}$ of dehydrogenated $\mathrm{Na}_{3} \mathrm{AlH} \mathrm{H}_{6}$, doped with 4 mol- $\%$ of $\mathrm{TiCl}_{3}$. The hydrogenation pressure was mostly $2.5 \mathrm{MPa}$ and the operating temperature of the hydrogen storage material was varied between 423.15 and $443.15 \mathrm{~K}$. For the monitoring of the temperature evolution eight thermocouples were installed at different positions inside the tank. Three of them were located $183 \mathrm{~mm}$ from the inner surface of the lid connected to the heat exchanger. The other five were installed $40 \mathrm{~mm}$ from the same lid. The temperatures of the hydrogenation and dehydrogenation process as well as the position of the thermocouples are shown in Figure 7 and Figure 9. The hydrogen pressure in the tank and the hydrogen flow to the tank during the hydrogenation as well as the hydrogen flow from the tank during the dehydrogenation are shown in Figure 6 and Figure 8 respectively. The hydrogen flow during a hydrogenation test has been automatically changed according to the status of the hydrogen saturation of the hydride. The highest hydrogen flow achieved in the beginning of the test was about $53 \mathrm{l} / \mathrm{h}$. It decreased to zero when the cooling of the tank system started. The additional electrical heating was switched off before hydrogen was introduced into the reactor. The small changes of the hydrogen pressure dramatically influence the hydrogen flow (flow peaks at $110 \mathrm{~min}$ and at $121 \mathrm{~min}$ ), as can be seen in Figure 6. At the begining of the hydrogenation process the temperature was not equally distributed inside the powder, thus a temperature difference of $15 \mathrm{~K}$ was measured between 


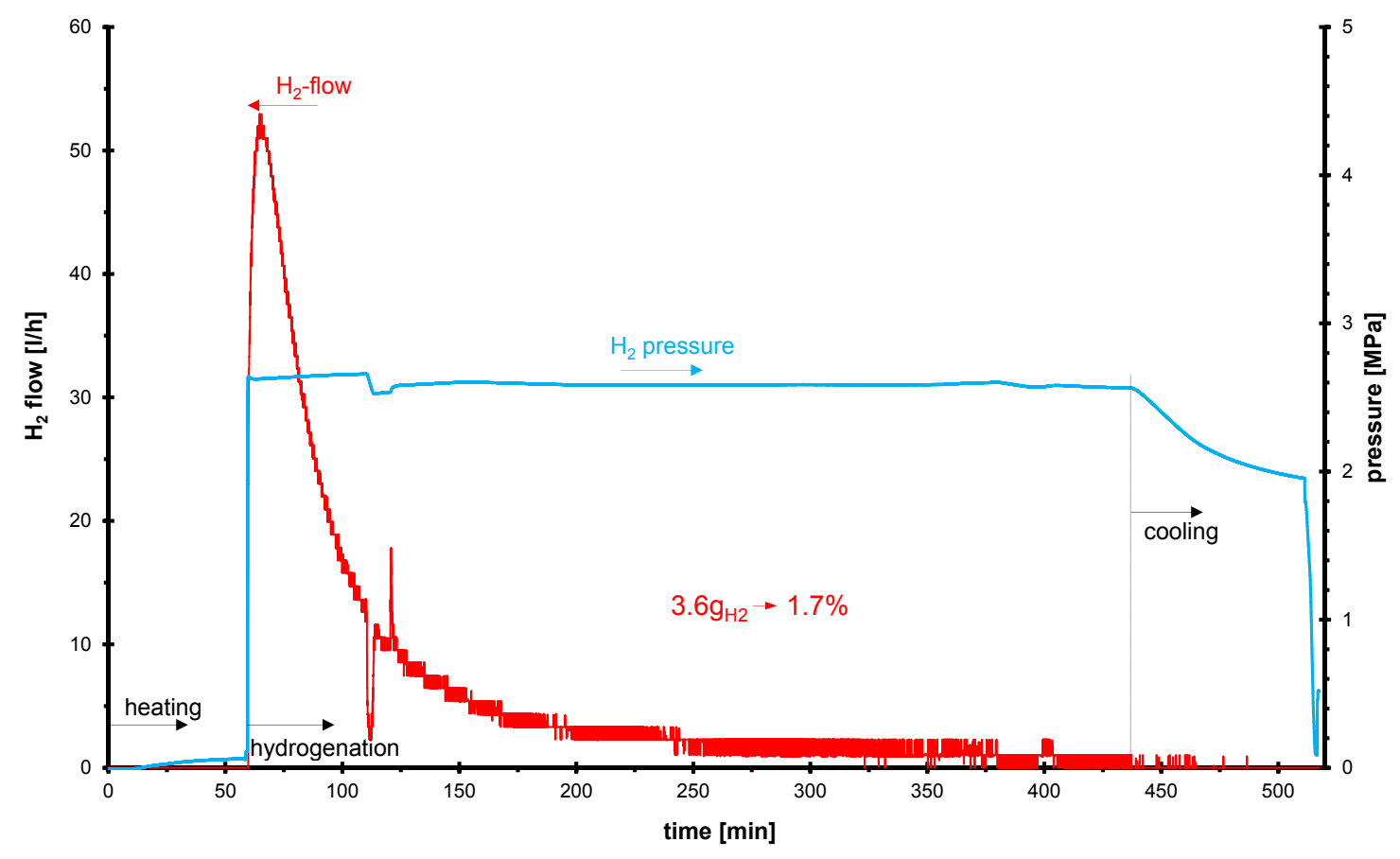

Figure 6: Hydrogen flow and pressure during hydrogenation

TC3 and TC5. At the end of the hydrogenation process, after $373 \mathrm{~min}$, the temperature was evenly distributed and the highest temperature difference measured in the hydride bed was only $4.3 \mathrm{~K}$ between TC3 and TC5. During this time the temperature difference (between TC1 and TC3) at the heat exchanger wall was $6.2 \mathrm{~K}$.

In this typical hydrogenation test an amount of $3.6 \mathrm{~g}$ (1.7 mass-\%) of hydrogen was stored in the hydride. During the hydrogenation process the hydrogen flow was measured by the mass flow meter (cf. MFM, Figure 5). When the hydrogenation had finished and the hydride has cooled down, the left over amount of hydrogen was exhausted by the mass flow controller (cf. MFC, Figure 5).

During the dehydrogenation test the hydrogen flow was stepwise reduced, to keep the hydrogen pressure in the tank at $0.65 \mathrm{MPa}$ (cf. from 140 to $215 \mathrm{~min}$ in Figure 8). In the beginning of the dehydrogenation process the hydrogen flow was about $62 \mathrm{l} / \mathrm{h}$. After the hydrogen flow was decreased to $22 \mathrm{l} / \mathrm{h}$, the hydrogen pressure increased slightly. At decreasing hydrogen pressure the hydrogen flow was kept constant at $5.6 \mathrm{l} / \mathrm{h}$ until the pressure reached 


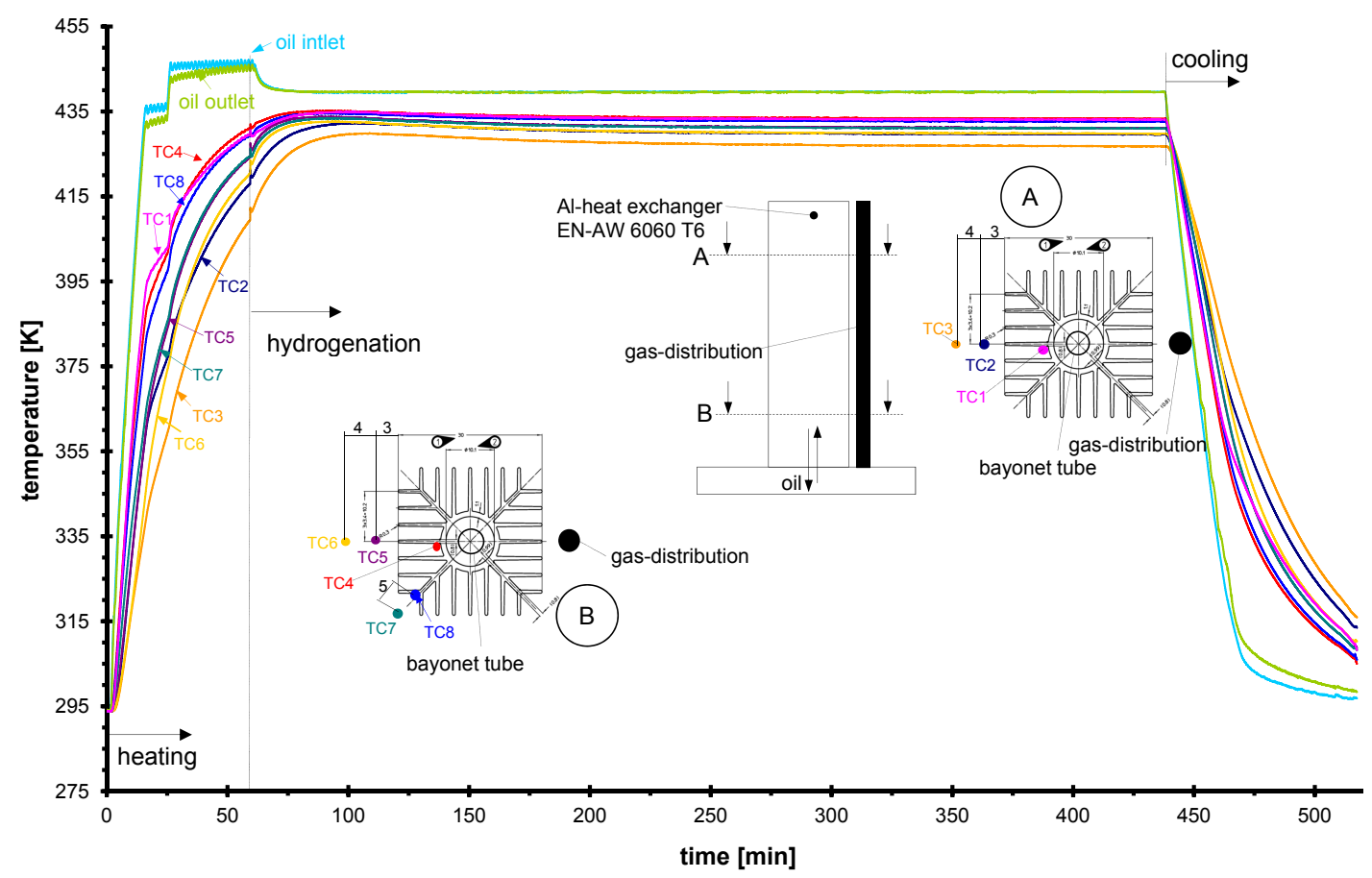

Figure 7: Temperatures during hydrogenation process and positions ot the thermocouples

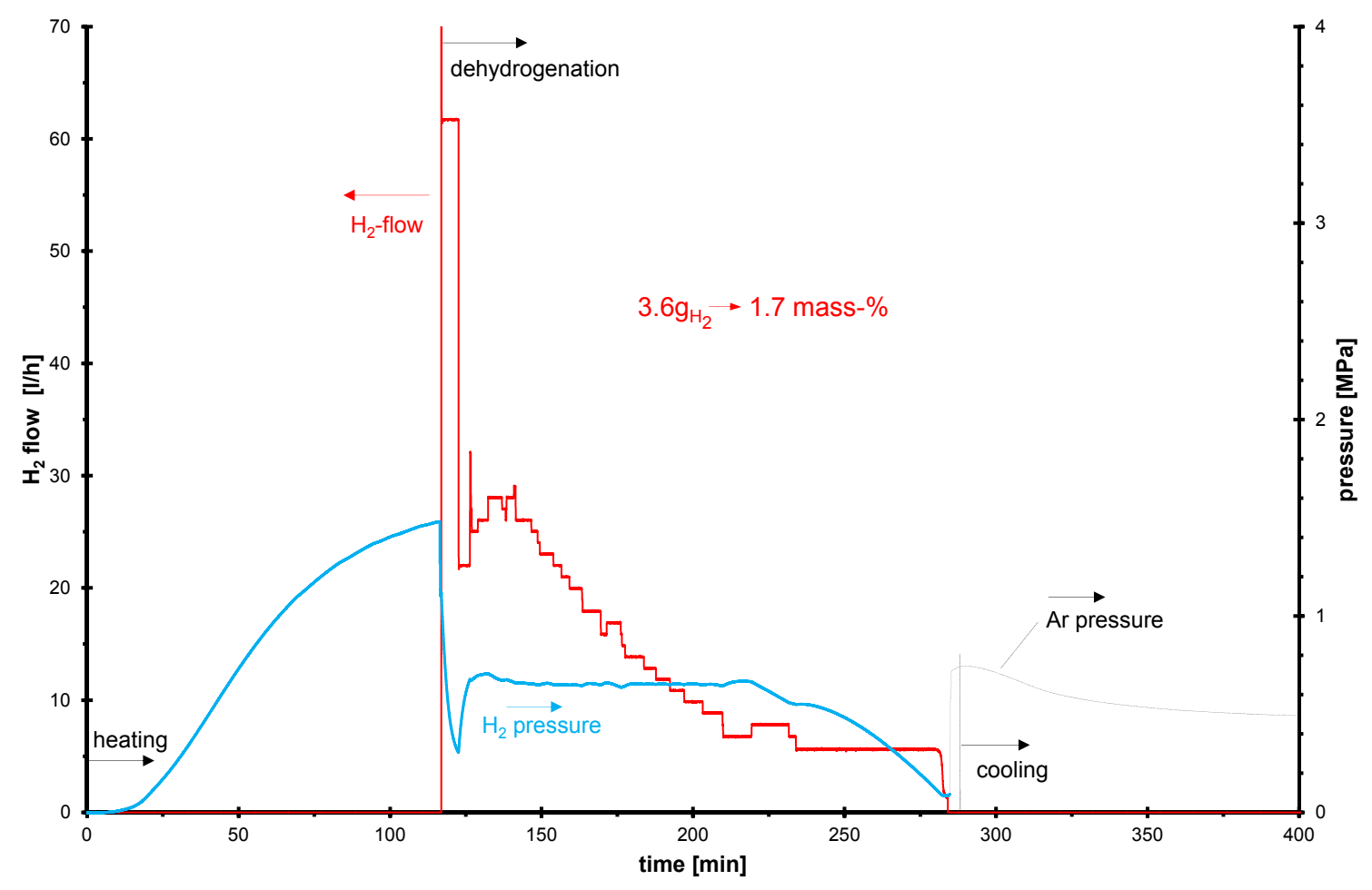

Figure 8: Hydrogen flow and pressure evolution during dehydrogenation 

TC8) dropped. The temperature gradient in all locations (in fin ground and in $3 \mathrm{~mm}$ and

$0.1 \mathrm{MPa}$.

The dehydrogenation test was started when the temperatures of the hydride reached 453.15 K (cf. verticle line in Figure 9). The lowest temperature of $450.15 \mathrm{~K}$ was measured at TC3, which located near the wall of the tank. At the beginning of the dehydrogenation all the temperatures inside the hydride and at the walls of the heat exchanger (TC1, TC4 and

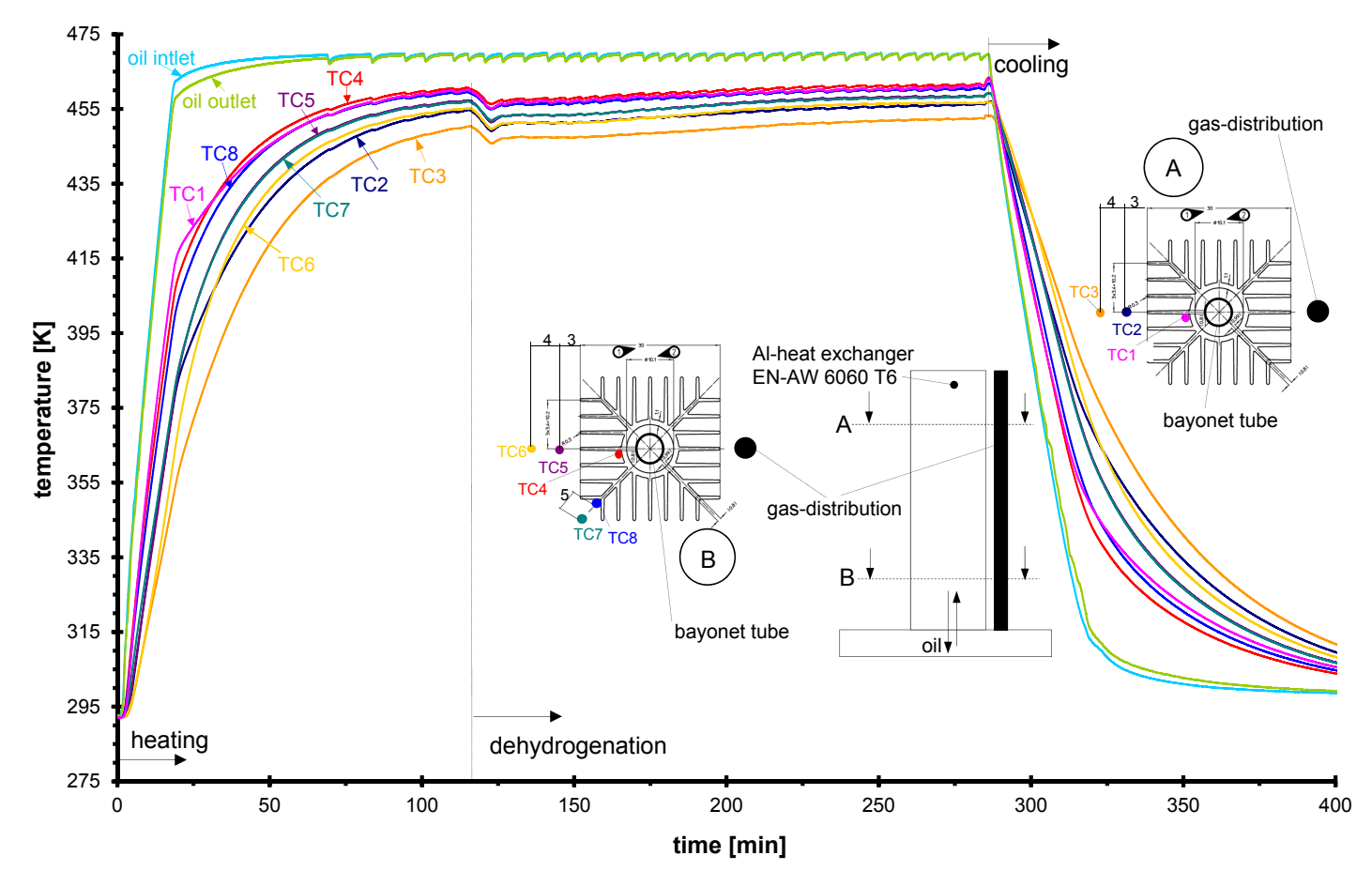

Figure 9: Temperatures during dehydrogenation process and positions of the thermocouples

$7 \mathrm{~mm}$ distance from the fin tip) was almost the same indicating an equal heat distribution in the tank. To avoid underpressure during the cooling process an inert gas (argon) was introduced into the tank (cf. Figure 8). The influence of the parasitic heat losses along the oil flow through the annulus of the heat exchanger have no important effect on the temperature development in the hydride (TC1 and TC4 are almost the same; cf. Figure 9). The temperature difference between the levels A (TC2) and B (TC5) during the dehydrogenation process was lower than $5 \mathrm{~K}$. During the hydrogenation the measured temperature difference was even less significant. Previously carried out hydrogenation or dehydrogenation exper- 
iments showed, that the temperature distribution around the investigated heat exchanger was quite equal at the two measured levels and thus independent from the not centrally located hydrogen distribution tube.

The inner reactor diameter was $53 \mathrm{~mm}$ and the edge length of the heat exchanger was $30 \mathrm{~mm}$, the maximal length from the end of the fin tip to the internal wall of the tank was $11.5 \mathrm{~mm}$. This design of the tank with this heat exchanger was less than ideal, because approximately $70 \%$ of the free volume was not occupied by the heat exchanger. As a result the temperature difference in the hydride at $7 \mathrm{~mm}$ distance from the fin tip towards the wall was quite high $(\approx 15 \mathrm{~K}$ in Figure 9 ). In a total 45 cycling test (hydrogenation and dehydrogenation tests) were carried out with this aluminium alloy tank charged with doped $\mathrm{Na}_{3} \mathrm{AlH}_{6}$.

\section{Conclusions}

A light weight aluminium alloy based tank system operated with a Ti-doped complex metal aluminium hydride $\mathrm{Na}_{3} \mathrm{AlH}_{6}$ was constructed and tested under hydrogenation and dehydrogenation conditions. Both the aluminium alloy parts of the tank as well as welded connections between these parts have withstood the operational pressure of 2.5 MPa during the hydrogenation and a temperature up to $463.15 \mathrm{~K}$ during the dehydrogenation. After a 45 cycling test neither failure of the aluminium alloy parts nor leakages were detected. During the hydrogenation/dehydrogenation processes up to $3.6 \mathrm{~g}$ (1.7 mass-\%) of hydrogen were stored and released. At this stage of development we were not interested in the optimization of the kinetics and capacity of the complex hydride material. The successful operation of the tank system was the main target. A forthcoming publication will address optimization of the complex metal hydride properties and construction of an aluminium alloy based tank system for $3 \mathrm{~kg}$ of the hydrogen storage material.

\section{Acknowledgments}

Financial support by Ministerium für Wirtschaft, Energie, Bauen, Wohnen und Verkehr des Landes Nordrhein-Westfalen and European Regional Development Fund (ERDF) (Fund- 
ing number: ef003a) as well as basic funding of the Max-Planck Society is greatly appreciated. The support by the enterprises TRIMET ALUMINIUM AG and FWB Bröckelmann Aluminiumwerk GmbH+Co.KG Germany is gratefully acknowledged.

\section{References}

AD Merkblätter, 2002. Verband der Technischen Überwachungs-Vereine e.V. No. 27. Heymanns Kölln.

Baehr, H. D., Kabelac, S., 2009. Thermodynamik, 14th Edition. Springer-Verlag Berlin Heidelberg.

Bogdanović, B., Eberle, U., Felderhoff, M., Schüth, F., 2007. Complex aluminum hydrides. Scripta Materialia $56(10), 813-816$.

URL http://www.sciencedirect.com/science/article/pii/S1359646207000437

Bogdanović, B., Schwickardi, M., May 1997. Ti-doped alkali metal aluminium hydrides as potential novel reversible hydrogen storage materials. Journal of Alloys and Compounds 253-254, 1-9.

URL http://www.sciencedirect.com/science/article/pii/S0925838896030496

Bogdanović, B., Spliethoff, B., Ritter, A., 1989. The magnesium hydride system for heat storage and cooling. Zeitschrift für Physikalische Chemie 164 (Part 2), 1497-1508.

URL http://dx.doi.org/10.1524/zpch.1989.164.Part_2.1497

Bürger, I., Hu, J., Vitillo, J., Kalantzopoulos, G., Deledda, S., Fichtner, M., Baricco, M., Linder, M., 2014a. Material properties and empirical rate equations for hydrogen sorption reactions in $2 \mathrm{LiNH}_{2}-1.1 \mathrm{MgH}_{2^{-}}$ 0.1 $\mathrm{LiBH}_{4}-3 \mathrm{wt} . \% \mathrm{ZrCoH}_{3}$. International Journal of Hydrogen Energy 39 (16), 8283 - 8292.

URL http://www.sciencedirect .com/science/article/pii/S0360319914005187

Bürger, I., Komogowski, L., Linder, M., 2014b. Advanced reactor concept for complex hydrides: Hydrogen absorption from room temperature. International Journal of Hydrogen Energy 39 (13), 7030 - 7041.

URL http://www.sciencedirect.com/science/article/pii/S0360319914004303

Bürger, I., Luetto, C., Linder, M., 2014c. Advanced reactor concept for complex hydrides: Hydrogen desorption at fuel cell relevant boundary conditions. International Journal of Hydrogen Energy 39 (14), 7346 -7355 .

URL http://www.sciencedirect.com/science/article/pii/S0360319914004297

Eberle, U., Muller, B., von Helmolt, R., 2012. Fuel cell electric vehicles and hydrogen infrastructure: status 2012. Energy \& Environmental Science 5, 8780-8798.

URL http://dx.doi .org/10.1039/C2EE22596D

EN 10027-2, 1992. Designation systems for steels; Part 2: Numerical system; German version.

EN 12392, 2000. Aluminium and aluminium alloys- Wrought products- Special requirements for products intended for the production of pressure equipment; German version. 
EN 13445, 2009. Unfired pressure vessels- Part 8: Additional requirements for pressure vessels of aluminium and aluminium alloys; German version.

EN 515, 1993. Aluminium and aluminium alloys; Wrought products; Temper designations; German version.

EN 573-2, 1994. Aluminium and aluminium alloys-Chemical composition and form of wrought products-Part 2: Chemical symbol based designation system; German version.

Jensen, J., Li, Q., He, R., Pan, C., Bjerrum, N., 2005. 100-200 C polymer fuel cells for use with $\mathrm{NaAlH}_{4}$. Journal of Alloys and Compounds 404-406 (0), 653-656, Proceedings of the 9th International Symposium on Metal-Hydrogen Systems, Fundamentals and Applications (MH2004). URL http://www.sciencedirect.com/science/article/pii/S0925838805009837

Jepsen, J., von Colbe, J. M. B., Klassen, T., Dornheim, M., 2012. Economic potential of complex hydrides compared to conventional hydrogen storage systems. International Journal of Hydrogen Energy 37 (5), $4204-4214$.

Johnson, T. A., Jorgensen, S. W., Dedrick, D. E., 2011. Performance of a full-scale hydrogen-storage tank based on complex hydrides. Faraday Discussions 151, 327-352.

Kang, B. H., Yabe, A., 1996. Performance analysis of a metal-hydride heat transformer for waste heat recovery. Applied Thermal Engineering 16 (8-9), 677-690.

URL http://www.sciencedirect.com/science/article/pii/1359431195000801

Li, H., Wang, X., Dong, Z., Xu, L., Chen, C., 2010. A study on 70 MPa metal hydride hydrogen compressor. Journal of Alloys and Compounds 502 (2), 503-507. URL http://www.sciencedirect.com/science/article/pii/S092583881001073X

Lozano, G. A., Eigen, N., Keller, C., Dornheim, M., Bormann, R., 2009. Effects of heat transfer on the sorption kinetics of complex hydride reacting systems. International Journal of Hydrogen Energy 34 (4), 1896-1903.

Lozano, G. A., von Colbe, J. M. B., Bormann, R., Klassen, T., Dornheim, M., 2011. Enhanced volumetric hydrogen density in sodium alanate by compaction. Journal of Power Sources 196 (22), 9254-9259.

Miura, S., Fujisawa, A., Ishida, M., 2012. A hydrogen purification and storage system using metal hydride. International Journal of Hydrogen Energy 37 (3), 2794-2799, 2010 AIChE Annual Meeting Topical Conference on Hydrogen Production and Storage Special Issue.

URL http://www.sciencedirect.com/science/article/pii/S0360319911007762

Mosher, D., Arsenault, S., Tang, X., Anton, D., 2007. Design, fabrication and testing of $\mathrm{NaAlH}_{4}$ based hydrogen storage systems. Journal of Alloys and Compounds 446-447 (0), 707-712.

Muthukumar, P., Groll, M., 2010. Metal hydride based heating and cooling systems: A review. International Journal of Hydrogen Energy 35 (8), 3817-3831.

URL http://www.sciencedirect.com/science/article/pii/S0360319910002120 
Ostermann, F., 2007. Anwendungsbuch Aluminium. Springer-Verlag Berlin Heidelberg.

Pfeifer, P., Wall, C., Jensen, O., Hahn, H., Fichtner, M., 2009. Thermal coupling of a high temperature PEM fuel cell with a complex hydride tank. International Journal of Hydrogen Energy 34 (8), 3457-3466. URL http://www.sciencedirect.com/science/article/pii/S0360319909002754

Psoma, A., Sattler, G., 2002. Fuel cell systems for submarines: from the first idea to serial production. Journal of Power Sources 106 (1-2), 381-383, Proceedings of the Seventh Grove Fuel Cell Symposium. URL http://www.sciencedirect.com/science/article/pii/S0378775301010448

Reddy, E. H., Jayanti, S., 2012. Thermal coupling studies of a high temperature proton exchange membrane fuel cell stack and a metal hydride hydrogen storage system. Energy Procedia 29 (0), 254-264.

URL http://www.sciencedirect.com/science/article/pii/S1876610212014518

Renouard-Vallet, G., Saballus, M., Schumann, P., Kallo, J., Friedrich, K. A., Müller-Steinhagen, H., 2012. Fuel cells for civil aircraft application: On-board production of power, water and inert gas. Chemical Engineering Research and Design 90 (1), 3-10.

URL http://www.sciencedirect.com/science/article/pii/S0263876211002693

Sattler, G., 2000. Fuel cells going on-board. Journal of Power Sources 86 (1-2), 61-67.

URL http://www .sciencedirect .com/science/article/pii/S0378775399004140

Schlapbach, L., Zuttel, A., Nov. 2001. Hydrogen-storage materials for mobile applications. Nature 414 (6861), $353-358$

URL http://dx.doi.org/10.1038/35104634

Urbanczyk, R., 2014. Experimentelle Untersuchung der thermischen Kopplung einer HT-PEM Brennstoffzelle mit einem Wasserstoffspeicher auf Basis von Natriumalanat. Ph.D. thesis, Universität DuisburgEssen.

URL http://duepublico.uni-duisburg-essen.de/servlets/DocumentServlet?id=33830

Urbanczyk, R., Peil, S., Bathen, D., Hesske, C., Burfeind, J., Hauschild, K., Felderhoff, M., Schüth, F., 2011. HT-PEM fuel cell system with integrated complex metal hydride storage tank. Fuel Cells 11 (6), 911-920.

Urbanczyk, R., Peinecke, K., Felderhoff, M., Hauschild, K., Peil, S., 8.-10. November 2012. Hydridspeicher aus Al-Legierungen zur Entkopplung von Wärme und Strom. In: Luschtinetz, T., Lehmann, J. (Eds.), Nutzung regenerativer Energiequellen und Wasserstofftechnik. Vol. 19 of Energie-Symposium. Fachhochschule Stralsund, pp. 111-115.

Utz, I., Schmidt, N., Wörner, A., Hu, J., Zabara, O., Fichtner, M., 2011. Experimental results of an aircooled lab-scale $\mathrm{H}_{2}$ storage tank based on sodium alanate. International Journal of Hydrogen Energy 36 (5), 3556-3565.

URL http://www . sciencedirect.com/science/article/pii/S0360319910023992 
van Hassel, B., Mosher, D., Pasini, J., Gorbounov, M., Holowczak, J., Tang, X., Brown, R., Laube, B., Pryor, L., 2012. Engineering improvement of naalh4 system. International Journal of Hydrogen Energy 37 (3), 2756-2766, 2010 AIChE Annual Meeting Topical Conference on Hydrogen Production and Storage Special Issue.

URL http://www.sciencedirect.com/science/article/pii/S0360319911003223

Verstraete, D., Hendrick, P., Pilidis, P., Ramsden, K., 2010. Hydrogen fuel tanks for subsonic transport aircraft. International Journal of Hydrogen Energy 35 (20), 11085-11098, Hyceltec 2009 Conference.

URL http://www.sciencedirect.com/science/article/pii/S036031991001236X

Weidenthaler, C., Felderhoff, M., 2011. Solid-state hydrogen storage for mobile applications: Quo vadis? Energy \& Environmental Science 4, 2495-2502.

URL http://dx.doi.org/10.1039/COEE00771D

Weiss-Ungethüm, J., Bürger, I., Schmidt, N., Linder, M., Kallo, J., 2014. Experimental investigation of a liquid cooled high temperature proton exchange membrane (HT-PEM) fuel cell coupled to a sodium alanate tank. International Journal of Hydrogen Energy 39 (11), 5931-5941.

URL http://www.sciencedirect.com/science/article/pii/S0360319914002079

Wierse, M., Werner, R., Groll, M., 1991. Magnesium hydride for thermal energy storage in a small-scale solarthermal power station. Journal of the Less Common Metals 172-174, Part 3 (0), 1111-1121, International Symposium on Metal-Hydrogen Systems, Fundamentals and Applications.

URL http://www.sciencedirect.com/science/article/pii/S0022508806800184

Willers, E., Groll, M., 1999. Evaluation of metal hydride machines for heat pumping and cooling applications: Evaluation des machines a hydrure metallique dans les applications de pompes a chaleur et de refroidissement. International Journal of Refrigeration 22 (1), 47-58.

URL http://www.sciencedirect.com/science/article/pii/S014070079700056X 